\title{
Victor and victim
}

\section{The true message of Frankenstein is about morality, not mad science.}

\section{Howard P. Segal}

$\mathrm{T}$ he increasing use of the word 'Frankenfood' by critics of genetically altered food is merely the latest instalment in the unending saga of anti-scientific sentiments allegedly originating with Mary Shelley's Frankenstein (1818). It bespeaks the novel's continuing influence that so many immediately recognize the derivation of the term. Yet 'Frankenfood' also echoes persistent distortions of the novel. Those who use Frankenstein to bash not just biotechnology but science overall have apparently never read the book, or have never read it carefully.

In truth, Frankenstein is hardly a Luddite tract - its message is not a call to destroy laboratories or experiments in the manner of the legendary English machine-breakers of the same period. Nor is its message akin to the famous 10-year moratorium on all scientific research proposed by the Bishop of Ripon in 1927.

Instead, Frankenstein insists that scientists must take moral considerations into account before, during and after research and development, and that they must assume responsibility for the outcomes both intentional and unintentional - of their experiments. Only if experiments prove harmful to society should they stop or be stopped. It is hardly surprising that Frankenstein is not more specific here. These now-commonplace positions were barely discussed in 1818, when science was largely the province of wealthy gentlemen whose research was immune from such regulations as university or governmental reviews of experiments on human subjects.

Contrary to the presentation of the story in most films and plays, what actually troubles Shelley about the scientist Victor Frankenstein is not so much his quest to

\section{rankenstein insists that scientists} must take moral considerations into account and assume responsibility for the outcomes of their experiments.

discover the "cause of generation and life" but rather the secretive, self-centred and finally self-destructive manner in which he pursues this primitive form of physiological engineering. Victor works alone, confides in no one and steadily abandons his family and friends in the attempt to win fame (but not fortune, as he is already well-to-do).

What further disturbs Shelley is not so much Victor's use of dead animals and people to construct his being as his indifference towards how the creature would look, would relate to its creator, and would function outside the laboratory. Victor builds an eight-foot-tall being simply because larger body parts are easier to work with. He never ponders his creature's appearance until he brings it to life.

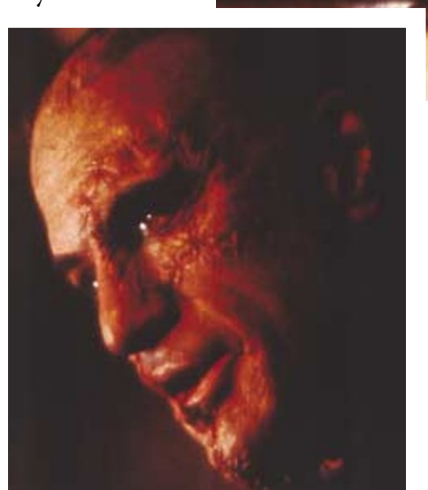

Indeed, it is critical to the novel's message that the creature is nameless. Contrary again to so many movie and stage versions, the name 'Frankenstein' belongs not to the creature but only to Victor and his family. Abandoned by Victor at 'birth', the unnamed being later compares its miserable plight to God's loving creation of Adam.

Yet it is too easy to characterize Victor as the quintessential mad scientist of most popular treatments. Rather, Shelley portrays him as extraordinarily self-centred. Victor himself notes that he is "not recording the vision of a madman". Instead, from the age of 15 until his death, he repeatedly blames "fate" for all his misfortunes. As Shelley understood, a truly mad scientist might escape moral responsibility for his actions.

Popular culture has also misrepresented the creature as an uncaring monster who kills innocent people without remorse. By now, 'Frankenstein' has nearly become a generic term for monster. In the novel, however, the creature feels guilty about its deeds and ironically, apart from appearance, is far more appealing than Victor. In fact, it is selfeducated, sensitive and articulate, unlike the ignorant, grunting beasts of most popular versions. The creature is thereby capable of becoming Victor's missing moral compass. If Victor blames "fate", the creature blames itself, planning to build a bonfire and commit suicide as penance for its actions. Had Shelley believed that scientists should not explore the "cause of generation and life", she would surely have portrayed a genuine moral monster.

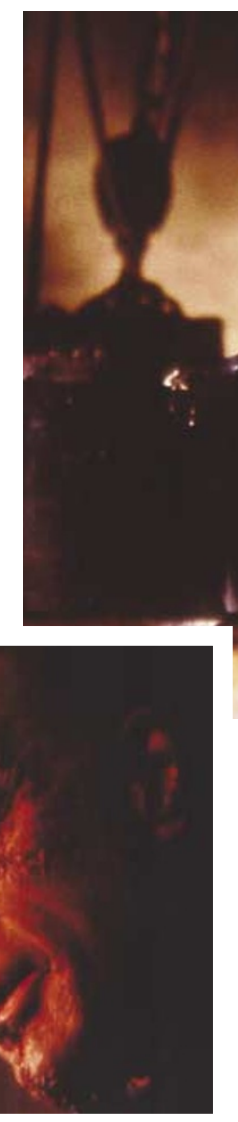
less outrageous than his abandonment of his creature. His replacement of female procreation constitutes a threat to women far greater than any presented by his creature. In this context, Victor's eventual refusal to satisfy his creature by completing a female companion for it - allegedly to prevent the couple from hurting other humans and from having offspring - is not a sincere ethical stance but rather a self-serving attempt to control both women and the creature.

Like many of her contemporaries, Shelley was fascinated by reports of electrical charges being used to produce temporary signs of life in corpses and by speculation over the potential uses of both electricity and chemistry to create new life forms. One can certainly imagine her endorsing experiments in genetic engineering if they were conducted with the external scrutiny and the moral consideration utterly lacking in Victor's case.

Recent debates about cloning animals and eventually people, about stem-cell research creating and destroying life in the laboratory, and, of course, about 'Frankenfood' all clearly pose challenges to even the most fervent advocates of genetic engineering. Yet it is precisely such scientific and ethical dilemmas that engaged Mary Shelley and that make her original, undistorted Frankenstein more timely than ever.

Howard P. Segal is in the History Department, University of Maine, Orono,

Maine 04469-5774, USA. 